\title{
WAR IN THE BALKANS
}

Conflict and Diplomacy before World War I

\author{
Edited by \\ James Pettifer and Tom Buchanan
}




\section{Published in 2016 by \\ I.B.Tauris \& Co. Ltd \\ London $•$ New York \\ www.ibtauris.com}

Copyright editorial selection (C) 2016 James Pettifer and Tom Buchanan Copyright individual chapters (C) 2016 Enika Abazi, Tom Buchanan, Robert Evans, Bernd J. Fischer, Melina Grizo, Helen Katsiadakis, Jasmina Knezovic, James Pettifer, Christian Promitzer, Sabrina P. Ramet, Biljana Vankovska and Eric Beckett Weaver

The right of James Pettifer and Tom Buchanan to be identified as the editors of this work has been asserted by the editors in accordance with the Copyright, Designs and Patents Act 1988.

All rights reserved. Except for brief quotations in a review, this book, or any part thereof, may not be reproduced, stored in or introduced into a retrieval system, or transmitted, in any form or by any means, electronic, mechanical, photocopying, recording or otherwise, without the prior written permission of the publisher.

References to websites were correct at the time of writing.

International Library of Twentieth Century History 84

ISBN: 9781784531904

eISBN: 9780857739681

ePDF: 9780857726414

A full CIP record for this book is available from the British Library

A full CIP record is available from the Library of Congress

Library of Congress Catalog Card Number: available

Typeset in Garamond Three by OKS Prepress Services, Chennai, India Printed and bound by CPI Group (UK) Ltd, Croydon, CR0 4YY 


\title{
CHAPTER 4
}

\section{COMBATING CHOLERA DURING THE BALKAN WARS: THE CASE OF BULGARIA}

\author{
Christian Promitzer
}

Among the many and manifold aspects that render the brutal campaigns of 1912-13 in the Balkans the harbingers of World War I issues of health and physical integrity are not among the least important. The challenges of military medicine and the task of saving the population in the hinterlands from epidemics that were rampant on the front line became particularly topical because of the imminent danger of a general war on the European continent. But the challenges military medicine had to face were different than those in former wars: surgeons, in the first case, had to deal with complicated wounds that had been caused by various forms of modern bullets, for the first time tried out on human flesh in these two wars. Of even greater significance were war epidemics: the Balkan Wars were the first theatre where methods of bacteriology were applied on a large scale, in order to analyse and attempting to prevent the upsurge of contagious diseases among the soldiers and the civilian population. Consequently, the First Balkan War became notable for the reason that "for the first time in a European war zone the modern doctrines of bacteriology and the modern principles of control of epidemics were applied", as is expressed by the words of the Viennese immunologist Rudolf Kraus (1868-1932), who himself visited the theatre of war. ${ }^{1}$ The Austrian historian Indira Duraković critically 
speaks of the warring Balkan states as fields of experimentation for Austro-Hungarian doctors and students of medicine who could now deepen their theoretical insights by practical application. ${ }^{2}$ But how efficient were these moments, when the Report of the International Commission to Inquire into the Causes and Conduct of the Balkan Wars tells us about "the black flags, hanging outside the doors of the hovels, a dismal sign of the mourning caused by the war and its sad accompaniment, cholera". ${ }^{3}$

This chapter tries to single out the role of cholera in this conflict and in Bulgaria in particular; thereby it aims to scrutinise the perception of this war epidemic by medical doctors from the Habsburg Empire and Germany. In Europe cholera had unfolded its horrors for the first time in the early 1830s. As a war epidemic it became rampant during the Crimean War, when in summer of 1854 on a stopover to the Crimea at the Black Sea port of Varna on the territory of modern Bulgaria, many French and British marines, foot soldiers and cavalrymen became victim to this pest, which they had brought along themselves. ${ }^{4}$ The other situation of war where cholera appeared was during the Austro-Prussian conflict of 1866. The Prussian army was heavily infested with cholera, and every Austrian area that was occupied by it contracted the epidemic. The Prussian army counted 12,000 cases of cholera, about 4,500 soldiers died of their wounds, but about 6,500 of cholera. The so-called generous conditions of the Prussian king were partly a result of time pressure due to cholera. ${ }^{5}$

Our concentration on Bulgaria proceeds from the fact that the Turkish medical historian Oya Daĝlar has already written an extensive study on the role of epidemics during the wars of the late Ottoman Empire. ${ }^{6}$ A similar account for Bulgaria is still missing, however. This is the more regrettable, because this country in both Balkan Wars occupied a central position both by terms of geography and military action; it consequently became an important turntable for the dissemination of cholera in the region. The example of Varna in 1854 shows cholera was not totally unknown in the region. In the years preceding the Balkan Wars, cholera had been observed in Bulgaria in 1910 with five fatal cases and in 1911 with 29 cases and 15 fatalities, ${ }^{7}$ all of whom had been introduced from Turkish citizens who had travelled to the Ottoman Empire. There, by May of 1911, cholera had taken more than 18,000 victims with more than 12,000 fatalities. ${ }^{8}$ 
As already mentioned, the second focus of this chapter lies on the interest in cholera, foreign - mainly Austrian and German - doctors showed at the time. Most of them were confronted with the epidemic during their voluntary service with the Red Cross. Historiography on their role in the Balkan Wars already exists. But the bulk of these works almost exclusively deals with the treatment of the wounded as part of international humanitarian work only. ${ }^{9}$ Within this framework the monograph of Konstantin Troshev on the mission of Czech doctors in the Balkan Wars forms an exception, because it also discusses broader issues of public health and military medicine in Bulgaria. ${ }^{10}$ Still more an exception is the contribution of Indira Duraković which gives an overview of several aspects of the missions of Austro-Hungarian doctors in the Balkans and of their perception of this region in particular. ${ }^{11}$ Some aspects of cholera in the Balkan Wars are furthermore addressed in an article written by Bulgarian authors whose findings rest on material from the Bulgarian Central Military Archive in Veliko Tarnovo. ${ }^{12}$ This chapter, in turn, concentrates itself upon the evaluation of the papers of the Austrian and German doctors involved in these missions and in their comparison with the accounts of their Bulgarian colleagues in order to reconstruct and to understand the significance of the cholera epidemic of 1912-13 and the applied methods of epidemic defence.

\section{A Turkish "Gift"}

One of the earliest international reactions to the presence of cholera in the conflict and the ensuing eventual dangers for the Western great powers originates from the German Ambassador to the Sublime Porte, Hans Freiherr von Wangenheim; on 15 November 1912, not even a month after the Bulgarian declaration of war, he reported to the German Ministry of Foreign Affairs that "according to information by reliable eyewitnesses, cholera, smallpox and typhoid are rampaging among the Turkish troops in Çatalca to an extent, that nobody can think about serious resistance". ${ }^{13}$ At the time, the victorious Bulgarian troops on their advance in eastern Thrace in bloody battles had already overrun the Ottoman fortresses of Kirkkilise, Lüle Burgaz and Pinarhisar. The Ottoman army had retreated to the fortifications of Çatalca, about 20 miles west of Istanbul, and the first and third Bulgarian army had already lined up vis-à-vis to the last Ottoman positions in front of 
Istanbul. Not only the Ottoman army, but also the Bulgarian troops were heavily infested with cholera, and an Ottoman rout back to Istanbul and an ensuing Bulgarian invasion of the Ottoman capital could not be excluded. The Europeans living in the city and the corps diplomatique of the great powers became uneasy, the German ambassador in another minute reported about "whole railway trains with soldiers sick of cholera arriving in San Stefano and even at the station of Sirkeci [in the European part of Istanbul], as well as bodies dead of cholera covering the areas alongside the railway and the front line of Çatalca". ${ }^{14}$ The epidemic had also grasped the Muslim civilian population of the immediate war zone and those parts of eastern Thrace that had been recently conquered by the Bulgarian units. Within a short period about 40-50,000 refugees arrived in Istanbul. They occupied cemeteries, courtyards of mosques and stations. According to the city government, about 20 to 50 new cases of cholera were daily registered, mainly among the Muslim refugees from the war zones. Big hotels and waterside residences at the Bosphorus, Schools and mosques had to be turned into hospitals. ${ }^{15}$

On 17 November the threat of infection by cholera by the two warring armies became the topic of the proceedings of the International Sanitary Council, which was the supreme public health authority of the Ottoman Empire and whose members to a major part were representatives of the great powers. On request of the British delegate this body appealed to the Ottoman authorities to prevent the entry of its troops and asked the governments of the great powers to act upon Bulgaria likewise to keep off its army from the Ottoman capital. ${ }^{16}$ At the same meeting the Ottoman minister of foreign affairs, Gabriel Effendi Nuradunghian, asked the foreign delegates of the Sanitary Council to support the city authorities in the fight against cholera. With respect to the numerous Europeans in the city and in the interest of international navigation the European representatives consented to this request and assigned 10,000 Turkish pounds for the fight against cholera. The money had to be spent for the protection of the water supply, warding off any military units, accommodation of cholera-infested or suspected persons, and for vaccination. A mixed commission of Ottoman and foreign members should monitor the disposition of the money. ${ }^{17}$

As is generally known, the Ottoman troops were able to maintain their position at the Çatalca line both in the period to the armistice of 
3 December and also after the resumption of fighting in early February 1913. Thus, the Ottoman capital was spared the mass entry of cholerainfested military units. Those soldiers, who would thereafter come from the war zones, would be isolated from the population. But still, until the end of 1912 more than 2,300 cholera cases were registered among the inhabitants of Istanbul, not including the many thousands of cases that had occurred in November among immigrants and returning soldiers from the front. The spread of the disease could be partly prevented by the daily bacteriological control of the water supplies of the city that had been implemented in the course of the events. ${ }^{18}$

This episode was supposed to show that the Balkan Wars were inextricably connected with war epidemics. In his monograph on the Balkan Wars Richard C. Hall describes the impotence of the Ottoman High Command to control the threat and the effects of cholera, but he also remarks that cholera became "a critical Ottoman weapon in the ... fight for Constantinople". ${ }^{19}$ In another place he again speaks about cholera as an "inadvertent Ottoman biological weapon". ${ }^{20}$ It is for certain that soldiers from Anatolia and Syria brought the epidemic to the Thracian theatre of war which had been free from cholera before the war. ${ }^{21}$ On the basis of the above quoted German sources one can at least contend that the Ottoman authorities were keen to reassure Western observers on the well-being of "European" inhabitants of Istanbul and on the future perspectives of international navigation.

\section{Cholera on the Bulgarian Side of the Frontline}

In the following part of my paper I will deal with the other side of the frontline and give a mirror-inverted image of the development of cholera on the Bulgarian side: I will shed additional light on the sanitary aspects of the warfare in eastern Thrace and give information on the contemporary Bulgarian discussion of the sanitary mistakes of the Bulgarian army as well as on the consequences for the civilian population. By doing so, I will make use of the observations of two Bulgarian medical doctors and of the accounts of Austrian and German doctors volunteering in the war zones. Here, I will only introduce the Bulgarian witnesses: The first is Toshko Petrov (1872-1942), who had a specialisation in hygiene and was member of the mobile hygienicdisinfecting unit of the First Bulgarian Army in eastern Thrace; this unit 
included the heads of the institutes of bacteriology and of hygiene in Sofia ${ }^{22}$ and disposed of a microbiological laboratory. ${ }^{23}$ The other person, whose account I will use, is the internist Vasil Mollov (1875-1938) who had already made a name in the international medical press by his examination of the distribution of malaria in Bulgaria. In 1913 he was the head of the epidemic hospital in Kirkkilise.

According to Petrov, after the battles of Lüleburgaz and Pinarhisar several dead bodies of Ottoman soldiers looked suspicious, because they showed no signs of being wounded, but had "the appearance of extremely drained and parched individuals". These bodies were often lying in rivers and swampy waters used for potable water of the Bulgarian army. ${ }^{24}$ An Austrian regimental doctor, Fritz Tintner, who volunteered in the Bulgarian campaign, observed that, due to lack of qualitative food supplies, Bulgarian soldiers regularly softened stale bread in these waters. ${ }^{25}$ These observations may hint at possible sources for infection with cholera. But the actual contamination of the Bulgarian army with the cholera pathogen happened when a reconnoitring Bulgarian cavalry regiment encountered an Ottoman infantry regiment before Çatalca; the cavalry repulsed the Ottoman unit and occupied its camp. ${ }^{26}$ Thenceforward the epidemic grasped the Bulgarian forces: From 5-6 November, when the main bulk of the two Bulgarian armies was still resting before resuming the march to Çatalca, doctors of the First Army observed the first cases of profuse diarrhoea and the first fatality. First bacteriological evidence of cholera was found on 9 November in a Bulgarian soldier in the town of Çorlu. ${ }^{27}$ Thereafter suspected and diseased soldiers were isolated in so-called "epidemic hospitals". The main hospital was erected in the Ottoman barracks of Çorlu, smaller ones were erected on other places in the hinterlands of the Çatalca front line. ${ }^{28}$ According to Italian and Russian examples the doctors administered the diseased soldiers the intake of a few drops of iodine tincture. The Bulgarian doctors further observed that several solders preferred to defecate in the outside. Consequently, the surroundings of the bivouacs soon turned into mud. From there the soldiers brought the matter inside with their boots. After they had taken them off, they would start to eat without washing their hands. In order to prevent this chain reaction and to compel the soldiers to use latrines, the orderly disposal of excrements was controlled by sentries. By these simple measures 
the first onslaught of cholera could indeed be averted in the First Bulgarian Army. ${ }^{29}$

Much more dramatic was the situation to its left among the 95,000 men of the Third Bulgarian Army, which was likewise on the increase to Çatalca. Around 10 November 400 suspected cases of cholera were counted among its ranks, and this number augmented to 7,000 cases by 16 November. ${ }^{30}$ The Third Army's only bacteriologist and his laboratory had been left behind in the recently conquered town of Kirkkilise. Therefore the mobile hygienic-disinfection unit of the First Army had to be transferred to the Third Army for assistance. This happened on 18 November, amidst the battle of Çatalca. The disinfection unit counted 23,500 cases of cholera and more than 2,200 fatalities. During the next four days another 5,700 cases and more than 600 fatalities had to be registered. ${ }^{31}$ The military historian Edward J. Erickson puts it bluntly: "Although its full effects had yet to be felt, cholera would ultimately kill and disable more Bulgarian soldiers than would Ottoman munitions." 32 Up to the armistice of 3 December almost 30,000 Bulgarian soldiers at Çatalca would fall sick of cholera; altogether more than 4,600 of them would be dead by that date. About one-sixth of the Bulgarian manpower was knocked out. ${ }^{33}$ At the same time, on the Ottoman side of the frontline, up to 20,000 soldiers suffered from cholera. ${ }^{34}$

The provisional epidemic field hospitals of the Bulgarian Army close to the frontline were equipped for 200 persons only. But in the aisles one could find 500 up to more than one thousand patients lying on the soil and in the cold. Each day several dozens of them lost their lives. ${ }^{35}$ At the sight of these conditions the already mentioned Viennese bacteriologist Rudolf Kraus remarked towards an official of the Bulgarian Red Cross with ill-concealed disdain: "With respect to the Bulgarian hospitals allow me to keep silent." 36

Many doctors initially misdiagnosed the disease as Gastro enteritis or as Gastro enteritis acutissima, and sought the reasons in bad food and exhaustion of the soldiers. ${ }^{37}$ Vasil Mollov contends that "the commanding officers and the army doctors were not allowed to proclaim the outbreak of cholera; ... they only did not mention cholera for fear of creating panic among the army. The soldiers, however, very well knew that cholera was rampaging among them. ${ }^{38}$ Only by way of bacteriological examinations could the mobile hygienic-disinfecting unit finally demonstrate that cholera was a concern. ${ }^{39}$ 


\section{The Spread of Cholera as a Consequence of Logistic Deficiencies}

A serious problem was the lack of isolation: the majority of the wounded soldiers contracted cholera during transport or in the field hospitals and in turn infected their fellow soldiers. Vasil Mollov explains this by the chaotic circumstances on the front lines:

The doctors of the units separated the cholera-infested, the latter often fell ill in the trenches and died there, other ones, when they observed the first signs, went to the hospitals nearby. The transport of the diseased from the units to the divisional lazarettos was realised in the most primitive way; usually the diseased walked a distance of several kilometres alone and they spread cholera everywhere; along the way one frequently could bounce upon the dead bodies of soldiers.

There were also many inapparent cases of cholera; they hardly showed any symptoms, but were nonetheless a source of infection. ${ }^{40}$

Toshko Petrov explained the dissemination of cholera among the Bulgarian forces not only with the deficient isolation of diseased soldiers, but also with the small number of bacteriologists. ${ }^{41}$ The lack of medical staff was a general problem, however, which could not be limited to a single professional branch: According to contemporary assessments the Bulgarian Army was in need of about 1,300-1,400 doctors in order to grant a satisfying system of medical treatment. But Bulgaria altogether possessed only 680 doctors at the time. Of this number about 100 were serving in the army during peace times. ${ }^{42}$ Now also the civilian doctors, without any exception, had to be mobilised, which had the consequence that the civilian population of Bulgaria became devoid of qualified medical personnel. These circumstances may explain the willingness of the Bulgarian authorities to accept voluntary missions of foreign doctors.

Petrov furthermore complained about the behaviour of foreign bacteriologists, who had been invited by the staff of the Bulgarian army. Instead of remaining in the back areas in order to examine the wounded, sick and healthy soldiers coming from the theatre of war, they rather preferred to study the various cases of diseases at the front line and rushed to the main hospital in Corlu. ${ }^{43}$ This assessment is in 
contradiction with the observations of the Austrian army doctor Ambros Celewicz, however, who claimed that the major part of the foreign medical missions was retained in the hinterlands. ${ }^{44}$ Also the small Czech bacteriological detachment worked far from the front line in Plovdiv. ${ }^{45}$ Vasil Mollov, in turn, disapproved of the Bulgarian high command, which did not trust its own medical staff and could not believe that cholera was among the army. It spent about 100,000 Leva to summon Professor Rudolf Kraus and three of his assistants in order to check the findings of the Bulgarian doctors. "This behaviour of the high command", writes Mollov, "caused distrust among our bacteriologists and it was a completely unjustified insult of the rank of medical doctors." ${ }^{26}$ This criticism was all the more grave, because Kraus had been personally invited by the Supreme Commander of the Bulgarian forces, King Ferdinand. ${ }^{47}$ Toshko Petrov relates that Kraus "in the beginning, before he had a chance to examine a diseased person, expressed doubts that cholera was in concern". The Bulgarian bacteriologists had to show him 11 kinds of vibrio cholera, isolated from diseased persons. Kraus finally admitted that among workers of Kirkkilise who had cleaned the rifles of soldiers killed in action, cases of cholera had appeared. Kraus furthermore examined 98 diseased in the staging hospital of Kırkkilise, among whom he found several patients who had contracted cholera. Only thereafter was he persuaded that cholera was rampant. ${ }^{48}$ For his Bulgarian colleagues the actual labour of Kraus' expensive bacteriological mission remained "quite mysterious". Already on 10 December Kraus and his team left the still cholera-stricken country, maligned by his Bulgarian colleagues with the statement: "The flag bearer leaves, because there is nothing left to do." ${ }^{49}$

According to Kraus, the low mortality spoke against cholera: however, the way in which the epidemic developed in individual cases suggested otherwise. Bacteriological examination explained that both cholera and dysentery were concerned. Kraus consequently came to the assessment that only in one-sixth of the cases was cholera indeed a concern. ${ }^{50} \mathrm{He}$ also held the view that the relatively mild appearance of cholera was a consequence of the sanitary provisions and of the seasonal circumstances that were not favourable for the development of the cholera pathogen. ${ }^{51}$ In any case, after Kraus had assessed that cholera indeed was a concern, the Bulgarian soldiers had to give an oath to drink boiled water only and they were informed about the dangers of cholera. He furthermore ordered the separation of diseased soldiers from wounded ones already 
from the front line to the staging hospitals. ${ }^{52}$ Four additional bacteriological laboratories were established in eastern Thrace and four in Bulgaria proper, also a sanitary service for the civilian population of the occupied eastern Thracian territory was brought into being. ${ }^{53}$ Kraus furthermore used the occasion to check out the anti-cholera vaccine he had developed during the cholera epidemic of 1908 in St Petersburg. It was applied upon 3,000 wounded soldiers at the staging hospital of Kırkkilise from the second half of November until late December 1912. ${ }^{54}$

Petrov writes that it was impossible to isolate the front line from the hinterlands, because the wounded had to be transported to the rear areas. ${ }^{55}$ By this way cholera was brought to the Second Bulgarian Army back in the rear area that was engaged in the siege of the city of Adrianople. Also among the Serbian Danube Division, which assisted the Second Bulgarian Army there, cases of cholera were observed in December. ${ }^{56}$ Later that month a Bulgarian prisoner of war, who had contracted cholera, also infected the Ottoman garrison of Adrianople. In the following months until the capitulation, due to lack of food and clean water, more and more inhabitants would become victims of cholera, typhoid and dysentery. ${ }^{57}$

Far more alarming was the fact that cholera also invaded the interior of Bulgaria and even the war zone in Macedonia by the transport of Ottoman prisoners of war and of wounded Bulgarian soldiers to the rear area. The town of Yambol in eastern Bulgaria, which hosted a huge evacuation hospital, was the first place where cholera appeared. On 7 December it was observed among the wounded in the hospital, but already one week later, on 15 December, it had grasped the first two victims among the civilian population of the town. ${ }^{58}$ An Austrian bacteriologist observed that the coachmen who provided for the transport of goods to and wounded from the frontline were often carriers of cholera, and that one of the civilian victims had been in contact with the coachmen. ${ }^{59}$ Wounded soldiers, who were sent back to the central staging hospital in Sofia, were also infected with cholera. The first case of cholera occurred in Sofia on the night of 21-2 November. The missions of foreign doctors, who had been organised by the Bulgarian Red Cross, were informed immediately. This first case of cholera in the Bulgarian capital for a short period almost caused panic. On 24 November during a meeting of about 25-30 agitated foreign doctors at the Hotel "Balgariya" the Bulgarian doctor Petar Orahovats 
tried to calm the mood and declared that "Bulgaria serves as a barrier against the transmission of the disease to the West of Europe". The foreign doctors nonetheless formed a commission that worked out detailed suggestions of how to deal with persons that had contracted cholera. The Bulgarian government overtly accepted the plan, which consisted of rather general suggestions. ${ }^{60}$ Up to the beginning of the Second Balkan War altogether 34 cases of cholera were registered in Sofia. ${ }^{61}$ The AustroHungarian consulate in the north-western Bulgarian town of Vidin in late December nonetheless suspected that the Bulgarian authorities concealed cases of cholera that had occurred among the families of wounded soldiers who had returned home. ${ }^{62}$ Rudolf Kraus, in turn, after his return to Vienna declared that for the protection of the Bulgarian civilian population quarantining of returning soldiers would be useless; he rather suggested mass vaccination of the whole population. ${ }^{63}$ This suggestion was never put into practice, as we will see.

\section{Cholera in the Further Course of the Conflict}

After the expiration of the armistice, on 8 February 1913 fighting continued at Gallipoli. There members of the newly formed Fourth Bulgarian Army in the course of gathering the belongings of killed and wounded Ottoman soldiers became infected. ${ }^{64}$ The bacteriological laboratory back in Kirkkilise assessed cholera among them and was consequently transferred to the town of Uzunköprü on the way between Adrianople and Gallipoli - a measure that should have been taken already the previous November! In Uzunköprü also a staging hospital was established, while the respective mobile hygienic-disinfecting unit had the task to examine all diseased with diarrhoea; it had also to take care that no carrier of the disease could leave the town to any of the three war zones of Adrianople, Gallipolli and Çatalca. ${ }^{65}$

After the capitulation of Adrianople on 26 March, the commanding officers of the victorious Second Bulgarian Army did not listen to the warnings of the army doctors about the danger of infection in the city. ${ }^{66}$ The latter had elaborated a special plan for sanitising the town. It foresaw that the Bulgarian soldiers should not enter the town. Vasil Mollov remarks: "Sad to say, the plan was not executed; the soldiers had to file past the supreme commander and stayed within the town. Consequently, cholera appeared again and took the lives of about 1,000 
persons." 67 The surrendering town's Ottoman garrison, which since the beginning of the war had been isolated from its army and had since then to grapple with cholera and other epidemics all alone, was detained on an island in the river Tundzha ("Tunca" in Turkish); there they were left to die from starvation, cholera and other epidemic diseases. ${ }^{68}$ In the meantime the situation among the Bulgarian occupying forces and the remaining population in the town also deteriorated: the internal departments of the local hospital became crowded with diseased soldiers. Those who had contracted cholera were placed in a separate hospital on the periphery of the town for the purpose of isolation. The Austrian regimental doctor Karl von Müllern ascribed the fact that of the 1,200 patients only 200 died to the ample use of intravenous injections with saline solution. ${ }^{69}$ Already Kraus had observed that this treatment was at least as promising as the internal administration of iodine tincture. ${ }^{70}$

Due to the carelessness of the military authorites, one division that should have been transferred from Adrianople to Çatalca spread the disease anew among the other Bulgarian troops still engaged in the remaining theatres of war in eastern Thrace. ${ }^{71}$ Adrianople also became the springboard for a new round of infections in regard of the imminent Second Balkan War. The bulk of the Second Army, which in late May and early June was already on its march to its new positions in southern Macedonia, had cholera as its constant companion. In that period about 1,500 new cases had to be dealt with. ${ }^{72}$ In mid-June the AustroHungarian consul of Salonica reported 500 cases of cholera in the Bulgarian camps around Serres and Demir Hisar (today's Siridokastro) and 32 fatalities among the civilian population of a village nearby. ${ }^{73}$

Also the Fourth Army would take along cholera on its transfer from Gallipoli to the Macedonian theatre of war, so that at the beginning of the Second Balkan War about 6,500 cases were registered among its soldiers. ${ }^{74}$ Finally, the so-called Adrianople Brigade, which had been formed out of the Second Army, left the city without medical examination. It was infested with cholera and spread the epidemic on its way to Sofia and further on to its new positions within the newly formed Fifth Army around Kyustendil and Radomir in western Bulgaria. There, an additional 1,500 new cases of cholera were soon to be registered. ${ }^{75}$

In the early phase of the Second Balkan War the first cholera hospital was erected in Kyustendil, but due to the massive increase of cases among the Second and Fourth Armies additional field hospitals had 
to be established in western Bulgaria and in settlements in eastern Macedonia held by the Bulgarian forces, so that the epidemic according to Toshko Petrov - could be kept under control. ${ }^{76}$ In the two hospitals in Sofia providing for cases of cholera, altogether 1,805 cases were received; of these 155 (8.6 per cent) died. ${ }^{77}$ The claim that cholera was under control could only be postulated by ignoring the personal tragedy of the people in concern. Their lot is central to the retrospective novel Cholera by the Bulgarian author Ljudmil Stoyanov who tells us about two soldiers who contract cholera on the Macedonian front. They are bereft of medical treatment and have to beat their way back to the Bulgarian hinterlands on their own. Stoyanov's account is not an invention. In his criticism of the Bulgarian system of war medicine Vasil Mollov picks at individual army doctors who in time of cholera only looked on their own health and refused treatment. Some of them "even fenced themselves off by an impenetrable cordon". ${ }^{78}$

Toshko Petrov, in turn, contends that the consequences of the famous victories of the Bulgarian forces would have been totally different if there had not been the terrible assault of the cholera epidemic. With respect to the effect cholera had on the civilian population in Bulgaria he only laconically confesses that it took on a dramatic scale, and it was more disseminated in those regions of Bulgaria that were occupied by the Romanian and Serbian armies. ${ }^{79}$

\section{Criticisms and the Effect of Cholera on the Civilian Population}

In autumn 1913, after the lost second war, a disenchanted and indignant Bulgarian public looked at a potential culprit for the defeat; among others the medical profession as a whole came under criticism. In defence, Toshko Petrov declared that after the great battles of the first and the second war all 500 Bulgarian doctors had to deal with tens of thousands of wounded soldiers within a period of three or four days and that they had to treat more than 60,000 persons sick of cholera during the days of the Bulgarian assault on the Çatalca front line. ${ }^{80}$ The semi-official Bulgarian League of Doctors added that 3 per cent of the army doctors lost their lives in the combat against cholera. ${ }^{81}$ But both Petrov and the Bulgarian League of Doctors neglect the role of the 
600 volunteering foreign doctors who had been organised by the Bulgarian Red Cross on the initiative of its president, Doctor Stefan Vatev. The largest group among these volunteers were 150 doctors of Czech origin. ${ }^{82}$

But even so, it was undeniable that "[t] $\mathrm{t}$ he war ... showed our full bankruptcy in sanitary respect", as Vasil Mollov expressed it. ${ }^{83} \mathrm{He}$ ascribed part of the guilt to the drawbacks of the existing system of the army's sanitary inspection. Most of the drafted physicians were not instructed in the new plan for sanitary service in the army, which had been decreed two weeks before the beginning of the First Balkan War. ${ }^{84}$ The means of transport that were disposable for the diseased formed a problem by itself, since the Bulgarian forces "were at the end of a long and tenuous logistical system that relied in part on oxen for transportation”, as Richard C. Hall remarks. Vasil Mollov furthermore pointed out that "[o]ur means of transport for those with infectious diseases were the same as for wounded and even for foodstuffs. This was by no way harmless and ... a high percentage of the army supply trains was infected and [its staff] died of cholera." 85 But in general, Mollov contends that " $[t]$ hese mistakes are not those of the sanitary inspection, but of the general staff of the army which should have listened to the views of the sanitary part and yield to it unconditionally." ${ }^{86}$ Combating infectious diseases was the task of hygienists and bacteriologists. But their rating within the army was paltry:

The commanding officers looked at them like at superficial ballast, of whom they tried to be liberated from as quickly as possible, so that they left them behind in the rear of the army. Until the outbreak of cholera they were never consulted: indeed, their competency was subjected to daily questioning.

Only after the outbreak of cholera in November 1912 would this behaviour change. ${ }^{87}$

The discussion about the culprits for the loss of national pride took place without any notice of the suffering of the civilian population. To the contrary, the Bulgarian doctors' league boasted that Bulgarian doctors had refused to apply anti-cholera vaccines that had been bought at 60,000 leva by the government for the Bulgarian army. Under the pretext of saving Bulgarian soldiers from becoming the object of experiments, 
a possible means of prevention, which two other warring parties did use, was abandoned. ${ }^{88}$ But the missed chance of mass immunisation does not account for the whole tragedy. More important was the fact that the mobilisation of all doctors totally deprived the Bulgarian society of its customary system of healthcare. Vasil Mollov noted: "All doctors were taken into the ranks of the army, all [civic] hospitals were closed, even our first one - the Aleksander Hospital, and all the medical staff was taken to the army." ${ }^{" 89}$ Throughout the country, even the furnishings and instruments of the closed civic hospitals were taken for the military ones. ${ }^{90}$ An Austrian doctor observed that in regard of healthcare the municipalities were now dependent on provisional, so-called "feldshers" who had previously occupied different professions. Thus the Bulgarian sanitary service, which had worked well during peacetime, was almost totally incapacitated. ${ }^{91}$ Another Austrian doctor, who had been during the Second Balkan War in Bulgaria, remarked that "the medical treatment of the civilian population came to a halt. Even in Sofia, where some of the local civilian physicians remained, although they were now in military service, chronic diseases were not treated anymore." 92

Not only were the basic institutions of healthcare abolished, also the supreme administrative bodies of public health and the bacteriological institute in Sofia were disbanded. ${ }^{93}$ In this situation the attempt to instruct the civilian population to abstain from drinking unboiled water remained futile. ${ }^{94}$ For the common people the situation in the Second Balkan War was indeed more dramatic than in the first one. Now the capital was only 120 kilometres away from the front lines, and the whole western part of Bulgaria had become a deployment zone. The fairly good hygienic situation of the city did not allow for the breeding of the cholera pathogen; however, neither the water supply nor the sewage system were endangered. Consequently, cholera did not claim civilian victims among the inhabitants. ${ }^{95}$ But this was not the case in the northern parts of the country, which in the course of July were occupied by the Romanian army. In the town of Vratsa, about 100 kilometres north of Sofia, cholera was probably triggered by two Bulgarian renegade soldiers; it broke out on 16 July and lasted until 22 August. The local authorities did not undertake any measures, so that of the 547 registered cases 236 , i.e. the hight rate of 43 per cent, would die. ${ }^{96}$ As we will see, even these figures were far too low. By late August the AustroHungarian embassy reported 60 cholera fatalities in the town of Vidin, 
and by 8 September 17 cases with eight fatalities in the town of Ruse, as well as 14 fatalities in Veliko Tarnovo and 60 cases in the town of Svistov. ${ }^{97}$ Also these figures do not reveal the whole truth. Since 10 August, the day the Treaty of Bucharest was concluded, the Bulgarian soldiers - several of them infected - returned home. Consequently, the Bulgarian authorities declared the just mentioned regions as well as the district of Pleven as being infested by cholera. Only by mid-October was the number of new cases decreasing in this part of the country. ${ }^{98}$

In the town of Gabrovo, another town to the north of the Balkan mountain range, the mortality in the hospital was about 50 per cent. Not only was the population seized with panic at the cholera, the people were also terrified to go to the hospital and the police had to bring them by force. ${ }^{99}$ Bacteriological examination showed that the epidemic spread alongside watercourses and in particular alongside the Iskar River. ${ }^{100}$ Also in Plovidv, south of the Balkan Mountains, civilians from a distance up to 20 kilometres were brought on oxcarts to the local cholera hospital, where one-quarter of the 283 registered cases died. ${ }^{101}$ As we have said, the figures that circulated at the time were far too low: 25 years later a retrospective statistical examination of the cholera epidemic of 1913 in Bulgaria revealed a total sum of 19,205 cases, of which 9,548 were fatal. The figures confirmed that the highest number of cases was north of the Balkan mountain range; almost three-quarters of the cases were to be found in the districts of Vratcha, Vidin, Pleven and Veliko Tarnovo, whereby the Vratcha district alone counted more than 7,000 cases. ${ }^{102}$

\section{A Bulgarian "Gift"}

The cholera epidemic in the Bulgarian Army and among the Bulgarian civilian population also infected the invading armies. On its advance through eastern Thrace the Ottoman Army did not meet any serious military resistance, but it lost 4,000 men to the epidemic. ${ }^{103}$ In this situation the Ottoman doctors for the first time deployed the ample use of cholera vaccine, prepared by the Gülhane School of Medical Practice. ${ }^{104}$ But this measure could not prevent that within a year the original Turkish gift had been returned by the Bulgarians.

The Romanian army mainly contracted cholera via contact with the Bulgarian population in the districts north of the Balkan mountain range. The main seat of the epidemic was Orhanie (today's Botevgrad) 
with more than 900 cases. Altogether almost 15,000 cases of cholera and more than 1,600 fatalities were observed among the Romanian army. The Romanian doctors undertook mass vaccinations of the soldiers, and after the end of the war they tried to quarantine them on their way back home across the Danube. They also applied about half a million vaccinations to the civilian population of Romania, but all these measures could not prevent about 5,700 cases from appearing, of whom about 3,000 died. ${ }^{105}$ Richard C. Hall contends that "the outbreak of cholera in the Romanian army in Bulgaria acted as an incentive to resolve the conflict". ${ }^{106}$

Also the Serbian army suffered infection both during occupation of Bulgarian territory and in contact with the Bulgarian forces in Macedonia and in Serbia proper; the two main seats of infection were the Bregalnica River, where a major battle between the Serbian forces and the Fourth Bulgarian Army took place. From mid-July onwards the infection proceeded among the population of the town of Kumanovo for several weeks. The second focus of infection was the area between the Serbian towns of Zaječar to the north and of Pirot to the south. After the retreat of the Bulgarian forces, the advancing Serbian army and the returning Serbian population contracted cholera. About 1-2 per cent of the population of the district of Pirot became infected. After the war the disbanded soldiers disseminated the epidemic over the whole country. ${ }^{107}$ Altogether, 4,800 Serbian soldiers died of cholera in the Balkan Wars, of whom 4,000 in the Second Balkan War. ${ }^{108}$ In this number, cases of cholera among the Serbian civilian population are not included.

The Greek army was the only one that from the very beginning of the Second Balkan War conducted precautions by mass vaccination and revaccination of its soldiers and by the ample use of mobile field laboratories as well as by the application of disinfection. ${ }^{109}$ Consequently, the total number of cholera cases remained relatively small. These measures notwithstanding, in Salonika up to 20 cases of cholera per day were registered in July. ${ }^{110}$ In the central Greek staging hospital in the town of Siridokastro, which had been wrested from the Bulgarians, by the end of the war 431 cases were registered; of these 130 died, while the percentage of the two-times vaccinated soldiers was 10 per cent lower than the average (30 per cent). ${ }^{111}$ After the treaty of Bucharest the Greek army retreated from a part of the territory it had conquered, because it was assigned to Bulgaria. This 
caused the flight of about 12,000 persons who considered themselves Greeks or Turks to Siridokastro. There, all of them were vaccinated against cholera. ${ }^{112}$ But even these precautions could not prevent the Bulgarian prisoners of war from Serres spreading the epidemic to Salonica and further on to Athens. ${ }^{113}$

\section{Conclusion}

Compared to previous wars, the imperfect application of epidemic defence in the Balkan Wars, despite its perceived failure, at least helped to reduce the lethality among cases of cholera in the Bulgarian Army. This has partly to do with advances in hygiene and was a consequence of the insights of germ theory. It had become general knowledge that cholera was a water-borne disease and that the spread of its pathogens could be prevented by the use of clean potable water and by isolation of the diseased. Even if the principles emanating from this knowledge were not always applied during the two Balkan Wars, their lack would certainly become a topic of subsequent criticism. As for the Bulgarian civilian population, which was bereft of any medical treatment, this assessment is not valid, as the high lethality - almost the half of 20,000 diseased persons - suggest.

In the defeated Bulgaria the harsh criticism of healthcare during the two Balkan Wars led to a search for a solution in the sanitary problems with which the country had been confronted during the Balkan Wars. In autumn of 1915 the Bulgarian government was confronted with the possibility to participate in World War I on the side of the central powers, who promised the best chances to gain Macedonia, which had been the actual Bulgarian objective in the Balkan Wars. In this situation, some Bulgarian intellectuals reflected on how to use the lessons of the sanitary catastrophe in the two preceding wars for a better outcome. Everybody realised that the lack of native doctors had been a major reason for the precarious course of events. Therefore the Bulgarian public supported the foundation of the first Bulgarian medical faculty in Sofia, which did indeed take place in the last year of World War I. The other major issue was how to protect the civilian population in a sanitary respect, when all the physicians were recruited to the army. It was not a doctor, but a sociologist, the Social Democrat Iliya Yanulov, who on his own initiative founded the institution of 
hygienic councils. The idea was simple: in the absence of the doctors, the population was asked to nominate bodies that would be responsible for the enforcement of hygienic measures and the control of epidemics in a municipality. ${ }^{114}$

With respect to the Balkans in general, the dissemination of cholera in the course of the two Balkan Wars showed the central epidemiological role Bulgaria took in the region. Its soldiers contracted cholera from the almost defeated Ottoman Army at the front-line, and they in turn disseminated it among their enemies when they were themselves beaten during the Second Balkan War. Thus, similar to a Greek Gift, cholera was handed over to the respective victors.

With the onset of World War I the context would again drastically change. Most important was the fact that the Ottoman Empire became an ally of Bulgaria. With respect to military medicine nothing else can demonstrate this change better than the fact that the German hygienist and expert on tropical medicine, Hermann Mühlens, up to 1915 worked as a consultant of the Ottoman Army and thereafter would be in the service of the Bulgarian forces. Also the sanitary threats would change: in the Balkans cholera remained a minor threat up to 1916, but already in 1915 the first place as sanitary scourge would be occupied by typhus; malaria, in turn, would dominate both sides of the Salonika front until the end of World War I. ${ }^{115}$

\section{Notes}

1. R[udolf] Kraus, "Über Maßnahmen zur Bekämpfung der Cholera auf dem bulgarischen Kriegsschauplatz", Wiener klinische Wochenschrift, 26:7 (1913), p. 241.

2. Indira Duraković, "Experimentierfeld Balkan. Ärzte am Schauplatz der Balkankriege von 1912/1913”, Südost-Forschungen, 68 (2009), p. 303.

3. Report of the International Commission to Inquire into the Causes and Conduct of the Balkan Wars (Washington, DC, 1914), p. 236.

4. Cf. Matthew Smallman-Raynor and Andrew David Cliff, War Epidemics: An Historical Geography of Infectious Diseases in Military Conflict and Civil Strife, 1850-2000 (New York, 2004), pp. 417-41.

5. Cf. Stefan Winkle, Geißeln der Menschheit, Kulturgeschichte der Seuchen, 3rd edn (Düsseldorf, 2005), pp. 210-12.

6. Oya Daĝlar, War, Epidemics and Medicine in the Late Ottoman Empire (19121918) (Haarlem, Netherlands, 2008). 
7. I[van] G[olosmanov], "Svedeniya otnosno broya na zabolelite i umrelite ot holera v Balgariya ot 1893 do 1913", Balgarski meditsinski pregled za zarazni bolesti, mikrobiologiya i parazitologiya, 2:3-4 (1938) gos: 120-1.

8. I[van Konstantinov] Popivanov et. al., "Organizatsionni i epidemiologichni aspekti na borbata s holerata sred balgarskata voyska prez Balkanskata voyna", Asklkepiy / Asklepios, 19 (2006), p. 160.

9. K[onstantin]. Troshev, "Deyatel'nost cheshkih vrachebnyh missiy vo vremya Balkanskih voyn (1912-1913) v Bolgarii”, Asklepiy, 3 (1974), pp. 192-8; Vasil Topuzov, "Chuzhdestrannite sanitarni misii v Balgariya po vreme na Balkanskata voyna (1912-1913 g.)", in XXVIe Congres international d'bistoire de la médecine, Plovdiv, 20-25 Aout 1978. Actes du Congres I (Sofiya, 1978), pp. 61-2.

10. Konstantin Trošev [i.e. Troshev], Česti lékaři v Bulharsku v dobĕ Balkánských válek. (1912-1913) / Cheshki lekari v Balgariya prez Balkanskite voyni (19121913) (Prague, 1984), pp. $127-34$ and 189-90.

11. Duraković, "Experimentierfeld Balkan".

12. Popivanov et al., "Organizatsionni i epidemiologichni aspekti".

13. Political Archive (PA) of the Federal Foreign Office Berlin, Akten der Kaiserlichen deutschen Botschaft zu Konstantinopel pro 1911-1914 betreffend epidemische Krankheiten, No. 4457-XII-3, Constantinople, 15 November 1912.

14. Ibid., No. 4517-12-3, Constantinople, 22 November 1912.

15. Ibid.; cf. in detail Daĝlar, War, Epidemics and Medicine, pp. 12-22 and 30-4.

16. PA, Akten der Kaiserlichen deutschen Botschaft zu Konstantinopel pro 1911-1914 betreffend epidemische Krankheiten, No 4485-12-3, 18 November 1912.

17. Ibid., No. 4517-12-3, Constantinople, 22 November 1912; cf. Daĝlar, War, Epidemics and Medicine, 52-3, 72, 74 and 111.

18. Nuran Yildırım, A History of Healthcare in Istanbul, Health Organizations Epidemics, Infections and Disease Control - Preventive Health Institutions Hospitals - Medical Eduction, 2nd edn (Istanbul, 2010), pp. 95-7; Daĝlar, War, Epidemics and Medicine, p. 76.

19. Richard C. Hall, The Balkan Wars 1912-1913: Prelude to the First World War (London et al., Routledge, 2000), p. 31.

20. Ibid., p. 119.

21. Daĝlar, War, Epidemics and Medicine, p. 11.

22. Cf. T[oshko] Petrov, "Nyakolko dumi za holerata v balgarskata voyska prez voynata na Balkanite”, Letopisi na lekarskiya sayuz, 10:8-10 (1913), p. 505.

23. Popivanov et al., "Organizatsionni i epidemiologichni aspekti", p. 161.

24. Petrov, "Nyakolko dumi za holerata", p. 502.

25. Fritz Tintner, "Erlebnisse und Beobachtungen im Türkisch-Bulgarischen Kriege”, Der Militärarzt, 47:6 (1913), p. 88.

26. Ibid., p. 89.

27. Petrov, "Nyakolko dumi za holerata", pp. 502-3. According to the History of the War between Bulgaria and Turkey of 1932 the first signs of cholera were 
observed one day later - cf. Popivanov et al., "Organizatsionni i epidemiologichni aspekti”, pp. 157-8.

28. Petrov, "Nyakolko dumi za holerata", p. 503.

29. Ibid., pp. 503-4; on the rejection of latrines see [Hans] Eckert, "Die Rolle der Kontaktinfektion in der Epidemiologie der Cholera (Nach in Bulgarien gesammelten Erfahrungen)", Berliner klinische Wochenschrift, 50:50 (1914), p. 2326.

30. Popivanov et al., "Organizatsionni i epidemiologichni aspekti”, p. 158.

31. Petrov, "Nyakolko dumi za holerata", p. 504.

32. Edward J. Erickson, Defeat in Detail: The Ottoman Army in the Balkan Wars, 1912-1913 (Westport, CT, 2003), p. 129.

33. Hall, The Balkan Wars 1912-1913, p. 35. Rudolf Kraus counts 29,626 cases and 1,849 fatalities - he claims that only 5,000 of the cases were really cholera - cf. Kraus, "Über Maßnahmen zur Bekämpfung der Cholera”, p. 242. Baruch Davidoff, "Über die Choleraepidemien in Bulgarien während und nach dem Balkan- und Weltkriege" (Dental diss., University of Berlin, 1925), p. 11, in turn, calculates 47,217 cases, of which 5,203 died. Also Popivanov et al., "Organizatsionni i epidemiologichni aspekti," p. 158, speak of 41,165 cases and 5,244 fatalities for the same period.

34. Erickson, Defeat in Detail, p. 137.

35. Petrov, "Nyakolko dumi za holerata", p. 504.

36. St[iliyan] Kutinchev, Sanitarnata sluzba, Cherveniyat krast i Balkanskata voyna, Belezhki i vpechatleniya (Sofia, 1914), p. 97.

37. Petrov, "Nyakolko dumi za holerata", p. 504.

38. Dimitar Mollov, "Voenno-sanitarnoto delo prez vreme na voynata", Letopisi na lekarskiya sayuz, 10:8-10 (1913), p. 442.

39. Petrov, "Nyakolko dumi za holerata", p. 504.

40. Mollov, "Voenno-sanitarnoto delo," p. 442; cf. Kutinchev, Sanitarnata sluzba, pp. 80-2.

41. Petrov, "Nyakolko dumi za holerata", p. 505.

42. Trošev, Česti lékaři v Bulharsku, p. 132.

43. Petrov, "Nyakolko dumi za holerata", p. 505.

44. Ambros Celewicz, "Der bulgarische Sanitätsdienst auf dem thrazischen Kriegsschauplatz”, Der Militärarzt, 47:12 (1913), p. 169.

45. Trošev, Česti lékaři v Bulharsku, pp. 189-90.

46. Mollov, "Voenno-sanitarnoto delo", p. 442.

47. Tintner, "Erlebnisse und Beobachtungen", p. 89.

48. Petrov, "Nyakolko dumi za holerata", p. 506.

49. Kutinchev, Sanitarnata sluzba, pp. 219-20.

50. Kraus, "Über Maßnahmen zur Bekämpfung der Cholera", p. 242; see also Tintner, "Erlebnisse und Beobachtungen", p. 89.

51. Ibid., p. 89.

52. Kraus, "Über Maßnahmen zur Bekämpfung der Cholera”, p. 244; Tintner, "Erlebnisse und Beobachtungen", p. 89. 
53. [Rudolf Kraus, "Erfahrungen und Erlebnisse aus dem Balkankriege”, Berliner klinische Wochenschrift, 50:11 (1913), p. 521; Kraus, "Über Maßnahmen zur Bekämpfung der Cholera”, p. 242.

54. Ibid., p. 246; see also [Paul] Clairmont, "Bericht an die Österreichische Gesellschaft vom 'Roten Kreuz' über die Mission nach Bulgarien”, Der Militärarzt, 47:9 (1913), p. 140.

55. Petrov, "Nyakolko dumi za holerata", p. 506.

56. Austrian State Archives Vienna, Allgemeines Verwaltungsarchiv (AVA), Ministerium des Inneren, Sanitätsakten Sign. 34a, box 3072, No 7799/S, Vienna, 23 December 1912; Petrov, "Nyakolko dumi za holerata", p. 506.

57. Karl von Müllern, "Eindrücke und sanitäre Erfahrungen aus Adrianopel vom Standpunkte des Internisten”, Der Militärarzt, 48:11 (1914), p. 235.

58. Petrov, "Nyakolko dumi za holerata", p. 506.

59. K[lemens] I[sidor] Schopper, "Erfahrungen über die Cholera in Ostrumelien während des Balkankrieges 1912", Wiener klinische Wochenschrift, 26:10 (1913), p. 368. The author also found several cholera-infested coachmen around the village of Straldzha [Strandzha?] - ibid., pp. 367-8.

60. For the Bulgarian version, Petar Orahovats, "Sanitarnata sluzhba v Sofiya prez voynite 1912-1913 g.", Sbornik na Balgarskata akademiya na naukite 5 / Klon prirodo-matematichen 2 (1915), pp. 19-20; for the Austrian one, Josef Ballner, "Kriegschriurgische Erfahrungen aus dem Bulgarisch-Türkischen Kriege", Der Militärarzt, 47:10 (1913), p. 147; on the advent of cholera in Sofia see AVA Sanitätsakten Sign. 34a, box 3072, ad 88671/S, attachment, 16 December 1912; Schopper, "Erfahrungen über die Cholera in Ostrumelien", p. 367.

61. Orahovats, "Sanitarnata sluzhba v Sofiya prez voynite", p. 22.

62. AVA Sanitätsakten Sign. 34a, box 3072, No 120/S Blg. 1, Vidin, 27 December 1912.

63. Kraus, "Über Maßnahmen zur Bekämpfung der Cholera", p. 246.

64. Petrov, "Nyakolko dumi za holerata", p. 507.

65. Ibid.

66. Ibid.

67. Mollov, "Voenno-sanitarnoto delo", p. 442.

68. These horrors and other cruelties committed by Bulgarian soldiers are described by the Report of the International Commission, pp. 111-13; cf. Daĝlar, War, Epidemics and Medicine, pp. 100-1.

69. Müllern,"Eindrücke und sanitäre Erfahrungen”, pp. 236-7 and 262.

70. Kraus, “Über Maßnahmen zur Bekämpfung der Cholera”, p. 246.

71. Petrov, "Nyakolko dumi za holerata", p. 508.

72. Ibid.

73. AVA Sanitätsakten Sign 34a box 3984, No 4053/S, Salonika, 12 June 1913.

74. Petrov, "Nyakolko dumi za holerata", p. 508.

75. Ibid., pp. 508-9.

76. Ibid., p. 509.

77. Orahovats, "Sanitarnata sluzhba v Sofiya prez voynite", p. 22. 
78. Mollov, "Voenno-sanitarnoto delo", p. 444.

79. Petrov, "Nyakolko dumi za holerata", p. 509.

80. Ibid., p. 501.

81. Upravitelniyat savet na Lekarskiya sayuz v Balgariya, "Do redaktsiite na vestnitsite v Sofiya”, Letopisi na lekarskiya sayuz, 10:8-10 (1913), p. 518.

82. Celewicz, "Der bulgarische Sanitätsdienst", p. 171; cf. Trošev, Česti lékaři v Bulharsku.

83. Mollov, "Voenno-sanitarnoto delo", p. 434.

84. Ibid., p. 434; cf. Kutinchev, Sanitarnata sluzba, p. 34; Trošev, Česti lékaři v Bulharsku, pp. 131-2.

85. Mollov, "Voenno-sanitarnoto delo", p. 443.

86. Ibid., p. 442.

87. Ibid., p. 441.

88. N.N., "80. Prez vreme na voynata", Letopisi na lekarskiya sayuz, 10:8-10 (1913), p. 526; Kutinchev, Sanitarnata sluzba, p. 219.

89. Mollov, "Voenno-sanitarnoto delo", p. 437.

90. Orahovats, "Sanitarnata sluzhba v Sofiya prez voynite", p. 5.

91. Schopper, "Erfahrungen über die Cholera", pp. 367 and 370.

92. Bertold Reder, "Der Krankenzug der Österreichischen Gesellschaft vom Roten Kreuze auf dem bulgarisch-serbischen Kriegsschauplatz”, Der Militärarzt, 48:2 (1914), p. 34.

93. Orahovats, "Sanitarnata sluzhba v Sofiya prez voynite", p. 5.

94. Oskar Hanasiewicz, "Aus den bulgarischen Kriegsspitälern zu Dedeagatsch, Jamboli und Sofia während des Balkankrieges 1912-13”, Wiener klinische Wochenschrift, 27 (1914), p. 819; cf. Duraković, "Experimentierfeld Balkan", p. 307.

95. Eckert, "Die Rolle der Kontaktinfektion”, p. 2327.

96. H.N., "Holerata v Vrattsa", Letopisi na lekarskiya sayuz, 10:8-10 (1913), p. 516.

97. AVA Sanitätsakten Sign. 34a, box 3072, No 5778/S, Vienna, 26 August 1913, No 6039/S, Vienna, 3 September 1913, No 6275/S, Vienna, 11 September 1913.

98. AVA Sanitätsakten Sign. 34a, box 3072, No 7598/S attachment 2, 20 October 1913.

99. Franz Rosenthal, "Medizinische Eindrücke von einer Expedition nach Bulgarien, speziell ein Beitrag zur Diagnose und Therapie der Cholera asiatica", Berliner klinische Wochenschrift, 51:8 (1914), p. 344.

100. Victor Babes, "Studien über Cholerabekämpfung”, Zeitschrift für Hygiene und Infektionskrankheiten, 77 (1914), p. 503.

101. Rosenthal, "Medizinische Eindrücke von einer Expedition nach Bulgarien", p. 344.

102. G[olosmanov], "Svedeniya otnosno broya na zabolelite i umrelite", p. 130.

103. Hall, The Balkan Wars 1912-1913, p. 119. 
104. Yıldırım, A History of Healthcare in Istanbul, p. 98; Daĝlar, War, Epidemics and Medicine, p. 103.

105. Babes, "Studien über Cholerabekämpfung", pp. 501-15, 525-6, 530. Hall, The Balkan Wars 1912-1913, p. 118, speaks of 6,000 fatalities of cholera among the Romanian army.

106. Ibid., p. 123.

107. [August] Aumann, "Welche Bedeutung kommt dem Kontakt bei der Verbreitung der Cholera in Serbien 1913 zu?”, Berliner klinische Wochenschrift, 51:2 (1914), pp. 62-3.

108. Report of the International Commission, p. 395; cf. Hall, The Balkan Wars $1912-$ 1913 , p. 135.

109. Konstantin J. Moutouses, "Die Cholerabekämpfung in der griechischen Armee während des griechisch-bulgarischen Krieges”, Der Militärarzt, 48:4 (1914), pp. 65-8.

110. Ibid., p. 68.

111. Ibid., p. 70.

112. Ibid., pp. 68-9.

113. Iv[an] Golosmanov, "Voyni i epidemii. II. Razprostranenie na zaraznite bolest mezhdu naselenie v vreme na voyni”, Balgarski meditsinski pregled za zarazni bolesti, mikrobiologiya i parazitologiya, 4:1-2 (1940), p. 115; Duraković, "Experimentierfeld Balkan," p. 316, speaks of 5,000 cases of cholera of whom 1,700 died.

114. Iliya Yanulov, Sotsialno zakonodatelstvo v Balgariya, vol. 2: Razvitie na socialnoto zakonodatelstvo v Balgariya (Sofia, 1939), pp. 117-32.

115. Peter Mühlens, "Kriegshygienische Erinnerungen", Archiv für Schiffs- und Tropenhygiene, 43:12 (1939), pp. 531-61; Christian Promitzer, "Typhus, Turks and Roma. Hygiene and Ethnic Difference in Bulgaria, 1912-1944", in Christian Promitzer, Sevasti Trubeta and Marius Turda (eds), Health, Hygiene and Eugenics in Southeastern Europe to 1945 (Budapest and New York, 2011), pp. $95-9$.

\section{Bibliography}

Aumann, [August], "Welche Bedeutung kommt dem Kontakt bei der Verbreitung der Cholera in Serbien 1913 zu?", Berliner klinische Wochenschrift, 51:2 (1914), pp. $62-4$.

Babes [i.e. Babeş], Victor, "Studien über Cholerabekämpfung”, Zeitschrift für Hygiene und Infektionskrankheiten, 77 (1914), pp. 501-33.

Ballner, Josef, "Kriegschriurgische Erfahrungen aus dem Bulgarisch-Türkischen Kriege”, Der Militärarzt, 47:10 (1913), pp. 145-53.

Celewicz, Ambros, "Der bulgarische Sanitätsdienst auf dem thrazischen Kriegsschauplatz", Der Militärarzt, 47:12 (1913), pp. 169-73.

Clairmont, [Paul]. "Bericht an die Österreichische Gesellschaft vom 'Roten Kreuz' über die Mission nach Bulgarien”, Der Militärarzt, 47:9 (1913), pp. 129-42. 
Daglar, Oya, War, Epidemics and Medicine in the Late Ottoman Empire (1912-1918) (Haarlem, Netherlands, 2008).

Davidoff, Baruch, Über die Choleraepidemien in Bulgarien während und nach dem Balkan- und Weltkriege, Dental diss., University of Berlin, 1925.

Duraković, Indira, "Experimentierfeld Balkan. Ärzte am Schauplatz der Balkankriege von 1912/1913”, Südost-Forschungen, 68 (2009), pp. 298-327.

Eckert, [Hans], "Die Rolle der Kontaktinfektion in der Epidemiologie der Cholera (Nach in Bulgarien gesammelten Erfahrungen)", Berliner klinische Wochenschrift 50:50 (1914), pp. 2326-8.

Erickson, Edward J., Defeat in Detail: The Ottoman Army in the Balkan Wars, 1912 1913 (Westport, CT, 2003).

G[olosmanov], I[van], "Svedeniya otnosno broya na zabolelite i umrelite ot holera v Balgariya ot 1893 do 1913", Balgarski meditsinski pregled za zarazni bolesti, mikrobiologiya i parazitologiya, 2:3-4 (1938), pp. 120-30.

"Voyni i epidemii. II. Razprostranenie na zaraznite bolest mezhdu naselenie v vreme na voyni", Balgarski meditsinski pregled za zarazni bolesti, mikrobiologiya $i$ parazitologiya, 4:1-2 (1940), pp. 113-30.

Hall, Richard C., The Balkan Wars 1912-1913: Prelude to the First World War (London, 2000).

Hanasiewicz, Oskar, "Aus den bulgarischen Kriegsspitälern zu Dedeagatsch, Jamboli und Sofia während des Balkankrieges 1912-13", Wiener klinische Wochenschrift, 27 (1914), pp. 819-21.

Kraus, [Rudolf], "Erfahrungen und Erlebnisse aus dem Balkankriege", Berliner klinische Wochenschrift, 50:11 (1913), p. 521.

"Über Maßnahmen zur Bekämpfung der Cholera auf dem bulgarischen Kriegsschauplatz", Wiener klinische Wochenschrift, 26:7 (1913), pp. 241-7.

Kutinchev, St[iliyan], Sanitarnata sluzba: Cherveniyat krast $i$ Balkanskata voyna: Belezbki i vpechatleniya (Sofia, 1914).

Mollov, Dimitar, "Voenno-sanitarnoto delo prez vreme na voynata", Letopisi na lekarskiya sayuz, 10:8-10 (1913), pp. 434-45.

Moutouses, Konstantin J., "Die Cholerabekämpfung in der griechischen Armee während des griechisch-bulgarischen Krieges”, Der Militärarzt, 48:4 (1914), pp. $65-71$.

Mühlens, Peter, "Kriegshygienische Erinnerungen", Archiv für Schiffs- und Tropenhygiene, 43:12 (1939), pp. 531-61.

Müllern, Karl von, "Eindrücke und sanitäre Erfahrungen aus Adrianopel vom Standpunkte des Internisten”, Der Militärarzt, 48:11 (1914), pp. 233-40 and 48:12 (1914), pp. 262-7.

H.N., "Holerata v Vrattsa", Letopisi na lekarskiya sayuz, 10:8-10 (1913), p. 516.

N.N., "80. Prez vreme na voynata", Letopisi na lekarskiya sayuz, 10:8-10 (1913), p. 526.

Orahovats, Petar, "Sanitarnata sluzhba v Sofiya prez voynite 1912-1913 g", Sbornik na Balgarskata akademiya na naukite 5 / Klon prirodo-matematichen, 2 (1915), pp. 1-136.

Petrov, T[oshko], "Nyakolko dumi za holerata v balgarskata voyska prez voynata na Balkanite", Letopisi na lekarkkiya sayuz, 10:8-10 (1913), pp. 501-9.

Popivanov, I[van Konstantinov], K[alin Stoyanov] Kanev, I[vaylo Tsvetanov] Zhivkov, D[imitar Simeonov] Shalamanov and G. Varbanov, "Organizatsionni i epidemiologichni aspekti na borbata s holerata sred balgarskata voyska prez Balkanskata voyna”, Asklkepiy/Asklepios, 19 (2006), pp. 157-62. 
Promitzer, Christian, "Typhus, Turks and Roma. Hygiene and Ethnic Difference in Bulgaria, 1912-1944", in Christian Promitzer, Sevasti Trubeta and Marius Turda, Health, Hygiene and Eugenics in Southeastern Europe to 1945 (Budapest and New York, 2011), pp. 87-125.

Reder, Bertold, "Der Krankenzug der Österreichischen Gesellschafts vom Roten Kreuze auf dem bulgarisch-serbischen Kriegsschauplatz”, Der Militärarzt, 48:2 (1914), pp. 33-45.

Report of the International Commission to Inquire into the Causes and Conduct of the Balkan Wars (Washington, 1914).

Rosenthal, Franz, "Medizinische Eindrücke von einer Expedition nach Bulgarien, speziell ein Beitrag zur Diagnose und Therapie der Cholera asiatica”, Berliner klinische Wochenschrift, 51:8 (1914), pp. 342-4.

Schopper, K[lemens] I[sidor], "Erfahrungen über die Cholera in Ostrumelien während des Balkankrieges 1912", Wiener klinische Wochenschrift, 26:10 (1913), pp. 366-70.

Smallman-Raynor, Matthew and Andrew David Cliff, War Epidemics: An Historical Geography of Infectious Diseases in Military Conflict and Civil Strife, 1850-2000 (New York, 2004).

Tintner, Fritz, "Erlebnisse und Beobachtungen im Türkisch-Bulgarischen Kriege", Der Militärarzt, 47:6 (1913), pp. 86-90.

Topuzov, Vasil, "Chuzhdestrannite sanitarni misii v Balgariya po vreme na Balkanskata voyna (1912-1913 g.)", in XXVIe Congres international d'bistoire de la médecine, Plovdiv, 20-25 Aout 1978. Actes du Congres I (Sofiya, 1978), pp. $61-2$.

Trošev [i.e. Troshev], Konstantin, Česti lékaři v Bulharsku v dobĕ Balkánských válek (1912-1913) / Cheshki lekari v Balgariya prez Balkanskite voyni (1912-1913) (Prague, 1984).

Troshev, K[onstantin], "Deyatel'nost cheshkih vrachebnyh missiy vo vremya Balkanskih voyn (1912-13) v Bolgarii", Asklepiy, 3 (1974), pp. 192-8.

Upravitelniyat savet na Lekarskiya sayuz v Balgariya, "Do redaktsiite na vestnitsite v Sofiya”, Letopisi na lekarskiya sayuz, 10:8-10 (1913), pp. 517-18.

Winkle, Stefan, Geisseln der Menschheit: Kulturgeschichte der Seuchen, 3rd edn (Düsseldorf, 2005).

Yanulov, Iliya, Sotsialno zakonodatelstvo v Balgariya, vol. 2: Razvitie na socialnoto zakonodatelstvo $v$ Balgariya (Sofia, 1939).

Yıldırım, Nuran, A History of Healthcare in Istanbul: Health Organizations - Epidemics, Infections and Disease Control - Preventive Health Institutions - Hospitals - Medical Eduction, 2nd edn (Istanbul, 2010). 